\title{
RATINGS AND STRATEGIES FOR THE DEVELOPMENT OF HIGHER EDUCATION IN WORLD PRACTICE: EXPERIENCE FOR UKRAINE
}

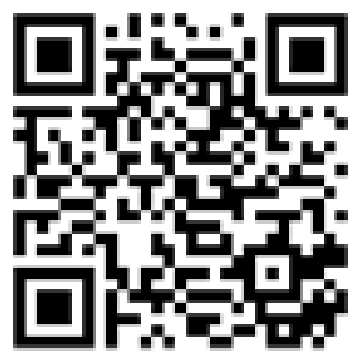

To cite this article:

\author{
Volodymyr Lugovyi, Dr. Sc., Prof. \\ First Vice-President, \\ National Academy of Educational Sciences of Ukraine \\ Kyiv, Ukraine \\ Luhovyi@ukr.net \\ https://orcid.org/0000-0003-1650-066X \\ Olena Slyusarenko, Dr. Sc., Senior Researcher \\ Vice-Director for Research, \\ Institute of Higher Education, \\ National Academy of Educational Sciences of Ukraine \\ Kyiv, Ukraine \\ Slyusarenko_o@ukr.net \\ https://orcid.org/0000-0001-7957-1794
}

Zhanna Talanova, Dr. Sc., Senior Researcher, Assoc. Prof.

Head of the Department,

Institute of Higher Education,

National Academy of Educational Sciences of Ukraine;

Analytical Manager,

National Erasmus+ Office in Ukraine

Kyiv, Ukraine

zhanna_t@ukr.net

https://orcid.org/0000-0003-4007-2677

Lugovyi, V., Slyusarenko, O., \& Talanova, Zh. (2021). Ratings and strategies for the development of higher education in world practice: experience for Ukraine. Education: Modern Discourses, (4), 90-102.

https://doi.org/10.37472/2617-3107-2021-4-09

\begin{abstract}
The paper shows the high efficiency of the Shanghai University Ranking for assessing the top quality of higher education and identifying national strategies for the development of the highest university potential across the world in 2003-2021. The strengths of this rating, which make it the most perfect today, are objectivity, validity, probability, reliability, transparency, clarity, parametric expediency, top-university mission compliance. Its application makes it possible to find out the main modifications of the university strategy-2 (strategy for the development of higher education of the highest quality). The most groundbreaking were France's strategic initiative to concentrate university resources by merging leading universities and China's strategy to consolidate universities and to provide strong targeted support to leading institutions. Concomitantly, in Japan, the lack of a holistic national strategy has led to multiple losses for both
\end{abstract}


world-class universities (in the top 500 group) and extra-class universities (in the top 30 group). Shanghai University Ranking showed an intensification of competition in the field of top higher education. The number of countries represented by universities in the top 30, top 100 and top 500 groups has increased. The US position has deteriorated, although it remains the world's absolute university leader. The second place is occupied by the United Kingdom. France moved to third place. As stated by the Shanghai University Ranking, Ukraine is increasingly lagging behind the progress of higher education in the world, is not included in the list of 63 countries / territories of the general version and up to 93 countries / territories of the sectoral (54 academic subjects) version of the 2021 rating. Ukraine needs the urgent development and implementation of national strategy-2 for the development of higher education.

Keywords: development; higher education; most perfect quality; rating; strategy-2; world experience, Ukraine.

\section{INTRODUCTION, PROBLEM STATEMENT}

Intensive development of university rankings during 2003-2021 and its use in practice has created new opportunities to identify the true state of higher education quality and develop adequate strategies to increase its competitiveness. At the same time, there was a problem of rating capacity of the ratings themselves, the selection of the most effective and recognized among them and outlining the scope of their application (Shanghai Ranking, 2021; THE ..., 2021; QS ..., 2021; Ranking Web ..., 2021; Salmi, 2009; Talanova, 2010; Slyusarenko, 2015; University Quality ..., 2015; Lugovyi, Slyusarenko \& Talanova, 2019; 2020; IREG ..., 2020; IREG ..., 2021; Cabinet of Ministers of Ukraine, 2018).

A number of author's publications of 2010-2021 has been systematically analysed the practice of implementing international and national university rankings in view of their objectivity, validity, probability, reliability, transparency, clarity, parametric expediency (meaning minimization of criteria and indicators), top-university mission compliance (i.e. compliance of the rating with the nature of the mission of the top university), etc. Furthermore, based on theoretical developments of higher education quality it is proved that university rankings are an integral part of the system of mechanisms for evaluating higher education, which are indispensable for determining the quality of the highest excellence (Talanova, 2010; Slyusarenko, 2015; Lugovyi, Slyusarenko \& Talanova, 2019; 2020; 2020a; 2020b; Lugovyi \& Talanova (eds.), 2018, 2020).

Therefore, the appropriately chosen rating provides a solid basis and guidelines for the formation of a strategy for the development of top-quality higher education. And the twodecade history of international rankings has created a significant heuristic body of empirical data on the implementation of strategies to increase the competitiveness of higher education in the world. This world experience is especially relevant for Ukraine, which, unlike accreditation mechanisms, in particular within the Bologna process, has failed to form the necessary and sufficient culture of modern university ranking. The lack of such practices is largely due to long-term indifference to determining the quality profile of higher education, identification and support of leading institutions, the lack of world-class universities among them. The latter poses a threat to Ukraine's national security, its self-sufficiency and, consequently, the country's sovereignty in the conditions of innovative type of progress and intensification of global competition (Shanghai Ranking, 2021; THE ..., 2021; QS ..., 2021; NAQA Ukraine, 2021; Talanova, 2010; Slyusarenko, 2015; Lugovyi, Slyusarenko \& Talanova, 2019; 2020; 2020a; 2020b; Lugovyi \& Talanova (eds.), 2018; 2020; World Bank Group, 2019; OECD, 2009, 2021, 2021a; Prezydent Ukrainy ..., 2020; 2021; Verkhovna Rada Ukrainy, 2014). 


\section{LITERATURE REVIEW}

The article is based on the following original publications.

Firstly, the annual data of international university rankings, specifically Shanghai Ranking, THE (Times Higher Education) World University Rankings, QS World University Rankings, Ranking Web of Universities (Shanghai Ranking, 2021; THE ..., 2021; QS ..., 2021; Ranking Web ..., 2021).

Secondly, analytical, and monographic materials on the creation of world-class universities, in particular J. Salmi (Salmi, 2009; Talanova, 2010; Slyusarenko, 2015; Lugovyi \& Talanova (eds.), 2018; 2020).

Thirdly, Organization for Economic Co-operation and Development (OECD), European University Association, IREG Observatory on Academic Ranking and Excellence, World Bank given the sphere of higher education in Ukraine (OECD, 2009, 2021, 2021a; University Quality ..., 2015; IREG ..., 2021; IREG ..., 2020; World Bank Group, 2019).

Fourthly, the authors' studies on international and national rating systems, university mission, the concept and characteristics of higher education quality, mechanisms for its evaluation and creation of profiles, scientifically sound recommendations for strategic development of national higher education and others (Lugovyi, Slyusarenko \& Talanova, 2019; 2020; 2020a; 2020b).

The use of literary sources is indicated in the presentation of main results.

\section{METHODOLOGY}

The article uses data from Shanghai Ranking for 2003-2021 to identify trends, specifics and national strategies and their results in the development of higher education of the highest excellence (Shanghai Ranking, 2021). The choice of ranking as a mechanism for assessing the top educational quality is based on its objectivity, validity, probability, reliability, transparency, clarity, etc. (Shanghai Ranking, 2021; Lugovyi, Slyusarenko \& Talanova, 2020a; 2020b; Lugovyi \& Talanova (eds.), 2020). The obtained characteristics of university achievements were compared with national strategic approaches and measures for university development (Lugovyi, Slyusarenko \& Talanova, 2020b; Lugovyi \& Talanova (eds.), 2020).

\section{MAIN RESULTS}

Recently, the ranking of higher education institutions (HEIs) has become an integral part of the world's advanced university practice. The particular importance to rating systems was the creation of the subject (sectoral) versions of ratings in addition to the general (institutional) one. Moreover, the results of longitudinal ranking have become valuable, which allows, along with static profiles of higher education quality, to identify dynamic changes of strategic nature in the development of HEIs, the total number of which exceeded 30,000. Rating uniqueness lies in its ability to identify the quality of the highest perfection, and thus, to form a strategy to achieve such quality of HEIs, the so-called strategy-2 (Shanghai Ranking, 2021; THE ..., 2021; QS ..., 2021; Ranking Web ..., 2021; NAQA Ukraine, 2021; Talanova, 2010; Slyusarenko, 2015; Lugovyi, Slyusarenko \& Talanova, 2019; 2020; 2020a; 2020b; Lugovyi \& Talanova (eds.), 2018; 2020; World Bank Group, 2019).

This rating-based strategy is fundamentally different from strategy-1 aiming at ensuring a minimum sufficient quality of higher education on the basis of accreditation (Fig. 1). 


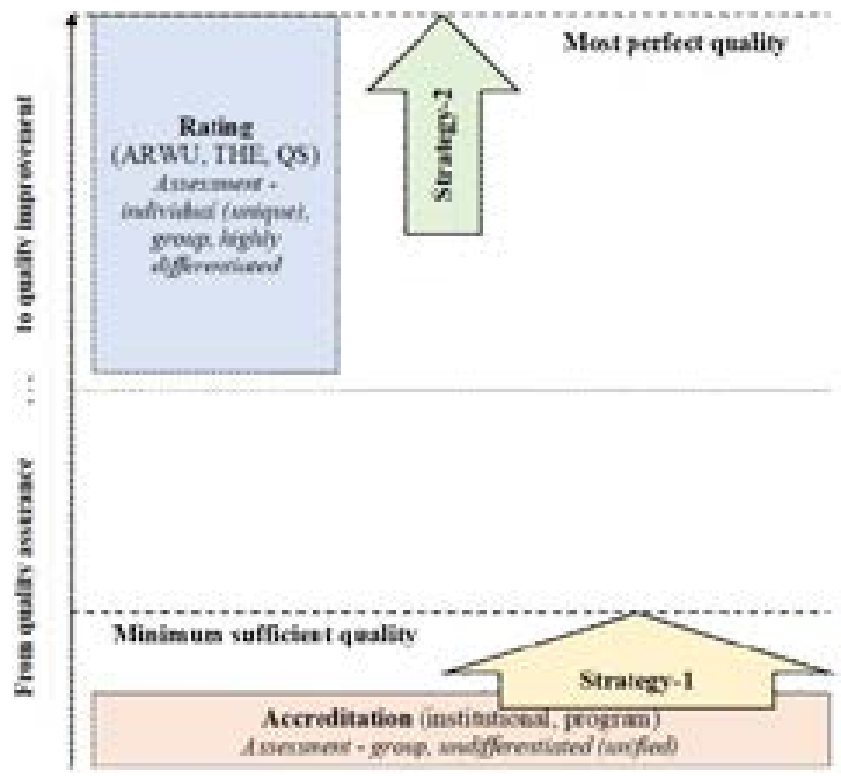

Fig. 1.

Strategies-1, -2 of development of higher education and appropriate mechanisms for its evaluation in the system "minimum sufficient quality - maximum perfect quality"

Source: Designed by authors.

Along with the expansion of the family of ratings, the problem of choosing the most objective, valid, probable, reliable, transparent, understandable of them became relevant. Authors' research has shown that Shanghai Ranking is the most adequate for diagnosing the highest university achievements. In particular, this rating has become the most popular for top universities, for example, in 1-30 positions of this rating (see Fig. 2).

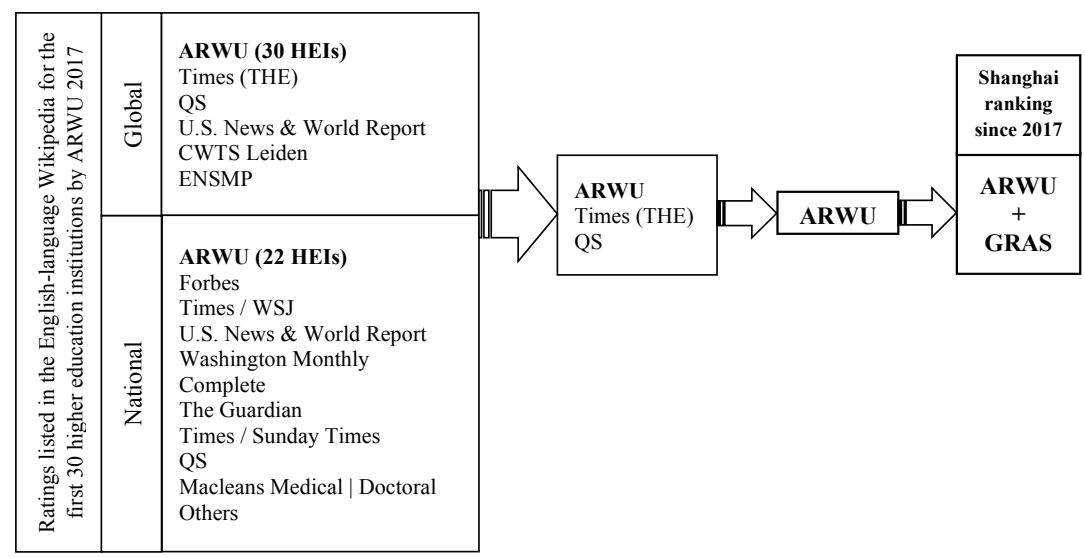

Fig. 2.

Shanghai ranking as the most popular among ratings listed in the English-language Wikipedia for the first 30 higher education institutions (HEIs) by ARWU 2017

Note: ARWU - Academic Ranking of World Universities; GRAS - Global Ranking of Academic Subject (Shanghai Ranking, 2021).

Source: Designed by authors based on: Lugovyi \& Talanova (eds.), 2018, pp. 79-81.

Since 2017, the Shanghai ranking has been represented simultaneously in two versions general (Academic Ranking of World Universities, ARWU) and sectoral (Global Ranking of 
Academic Subjects, GRAS), which systematically complete each other and allow to form a quality profile of higher education at the global, regional, national and institutional levels (Shanghai Ranking, 2021; Lugovyi, Slyusarenko \& Talanova, 2020; Lugovyi \& Talanova (eds.), 2020).

The long use of the general version of ARWU and the availability of relevant data enables us to identify the main modifications of strategy-2 for the development of top-quality higher education (Shanghai Ranking, 2021). This is important in the context of globalization and the intensification of the competitive basis of innovative progress (Lugovyi, Slyusarenko \& Talanova, 2020b; OECD, 2009, 2021, 2021a).

Fig. 3 shows how, for almost two decades, the number of world-class universities (WCUs) in the top 500 Shanghai Ranking in the eight countries represented by the extraclass universities (ECUs) in the top 30 ranking in 2021 has changed (Shanghai Ranking, 2021; Salmi, 2009; Slyusarenko, 2015). It should be noted that in 2003 there were 5 countries (in terms of ranking achievements in the United States, United Kingdom (UK), Japan, Canada, and Switzerland). Denmark, France, and China have also joined the top 30 in the process of competitive development of world higher education. At the same time, the rating order of countries has changed significantly, as can be seen from Fig. 3 .

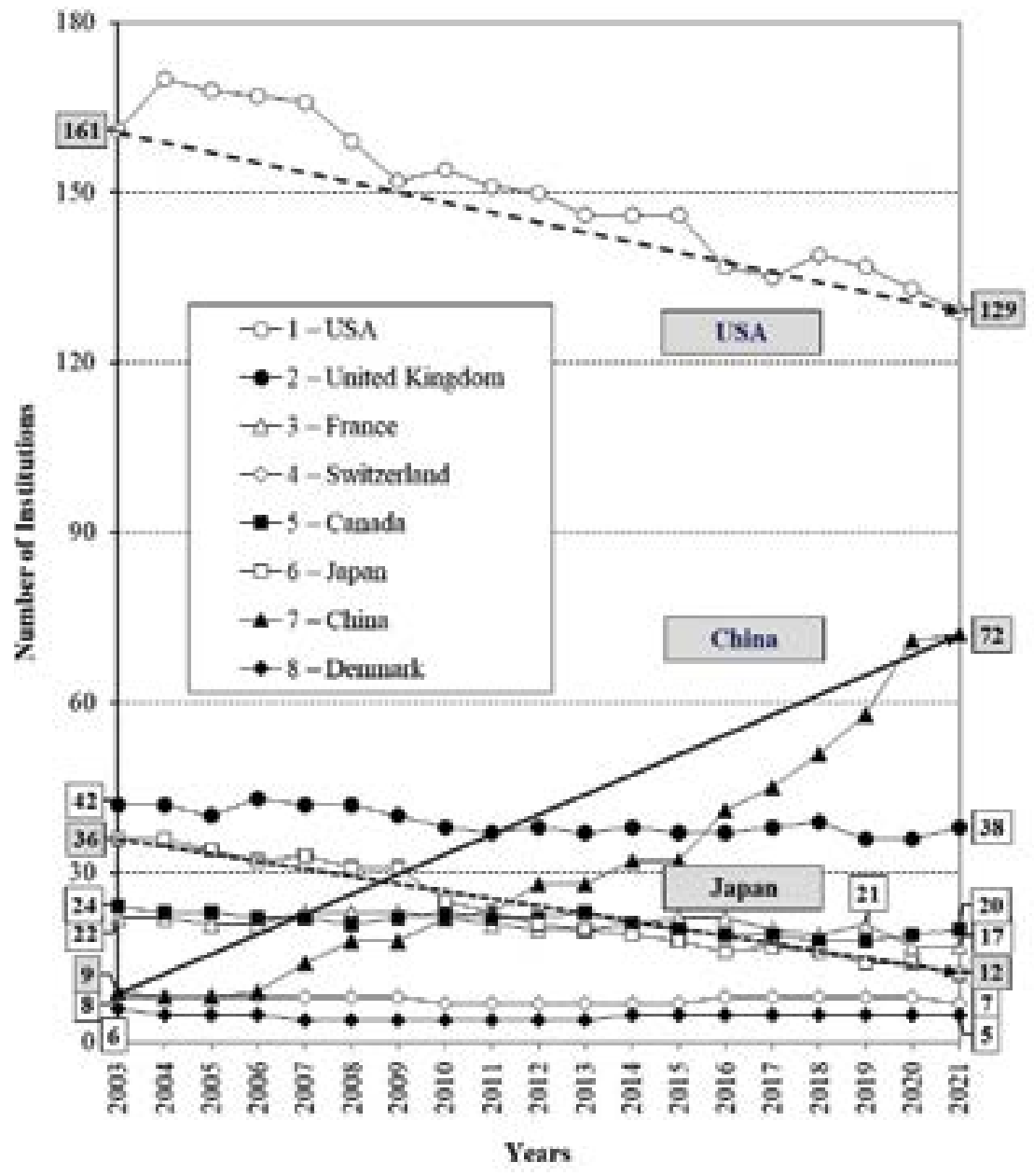

Fig. 3.

The number of world-class universities (1-500 rating places) in the countries represented

by higher education institutions in the top-30 group of the Shanghai ranking 2021, during 2003-2021

Source: Compiled by authors based on: Shanghai Ranking, 2021. 
From Fig. 3, it can be understood that countries have changed in different ways, firstly, the number of WCUs, and, secondly, their initial ranking order (determined by the level of ECUs). All countries have reduced the number of WCUs, except China, but to varying degrees: the most Japan - three times (from 36 to 12), the United States by 20\% (from 161 to 129), France by $22 \%$ (from 22 to 17), and other countries not so much (UK from 42 to 38 , Switzerland from 8 to 7, Canada from 24 to 20, Denmark from 6 to 5). At the same time, the developer of Shanghai Ranking China has increased the number of WCUs eightfold (from 9 to 72). France, China and Denmark are also in the top 30, which draws attention to their national strategies for the development of top higher education.

Fig. 4 shows from which starting places the last three countries have advanced since 2003: France from 11 to 3, China from 25 to 7 and Denmark from 12 to 8 positions.

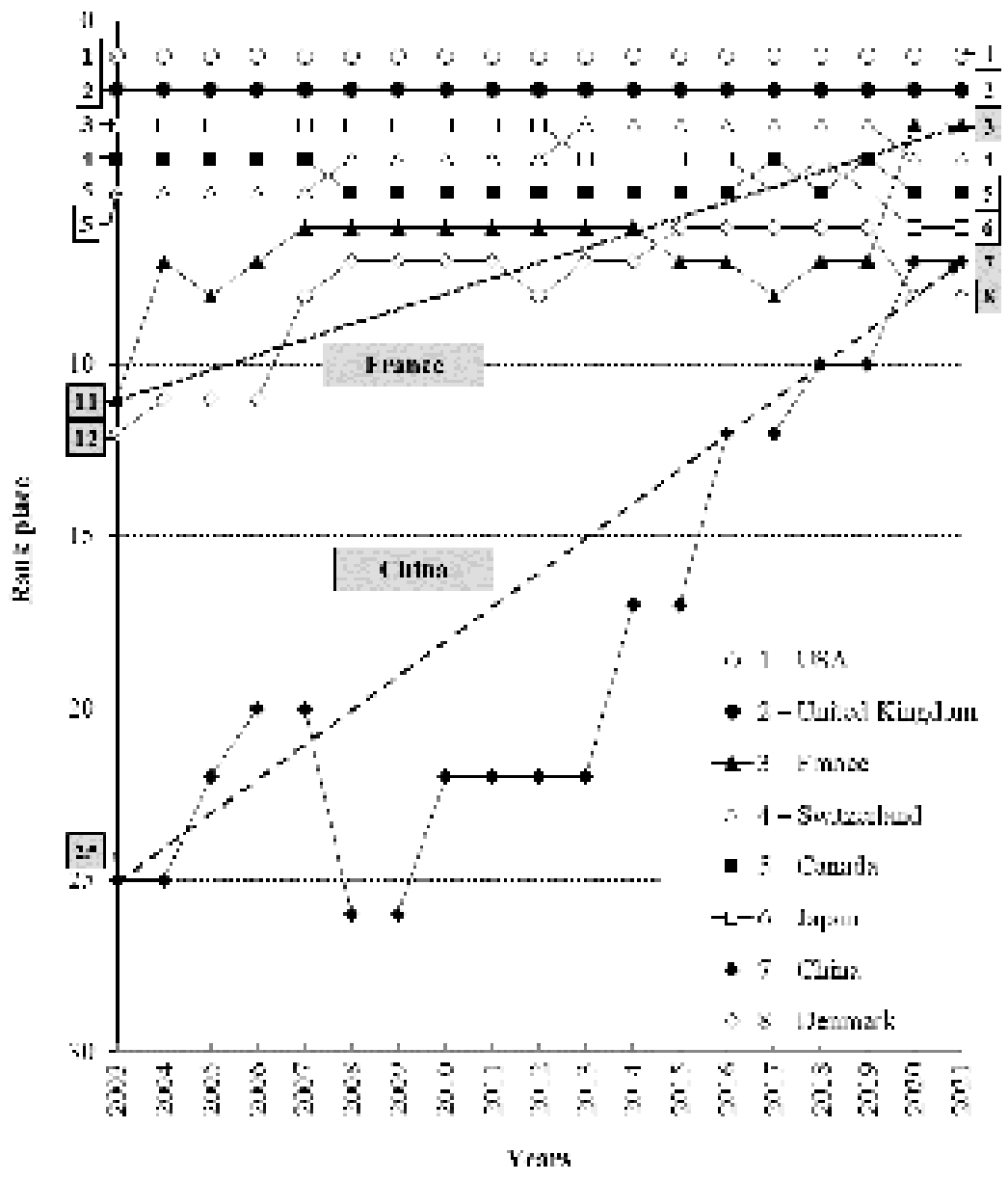

Fig. 4.

Ranking positions of the countries represented by universities in the top 30 group of the Shanghai ranking 2021, during 2003-2021

Source: Compiled by authors based on: Shanghai Ranking, 2021.

Fig. 3 and 4 show that from the achievements gained the French and Chinese versions (modifications) of strategy-2 were the most impressive. In France, by merging a number of top universities, in particular under the ten-year government program "Investing in Future", during 2018-2020, they reduced the total number of WCUs but formed the universities, including Paris-Saclay University, which turned France into the third university country in the 
world in 2020 and 2021 (Shanghai Ranking, 2021; Lugovyi, Slyusarenko \& Talanova, 2020b). In China, the existing leading universities were simultaneously enlarged and supported, thus significantly advancing the number of WCUs as well as in the established ECU. For example, Tsinghua University in 2003-2021 climbed from $201^{\text {st }}$ to $28^{\text {th }}$ place in Shanghai Ranking, i.e. it became the ECU (Shanghai Ranking, 2021; Lugovyi, Slyusarenko \& Talanova, 2020b).

From Fig. 5 it is possible to understand the power of the French modification of the strategy-2. After all, the ascent and fixing of the $14^{\text {th }}$ and $13^{\text {th }}$ positions of Paris-Saclay University in 2020 and 2021 was carried out in the conditions of high steepness of the rating distribution in the top 30 group and the corresponding strong stratification of HEIs according to their achievements.

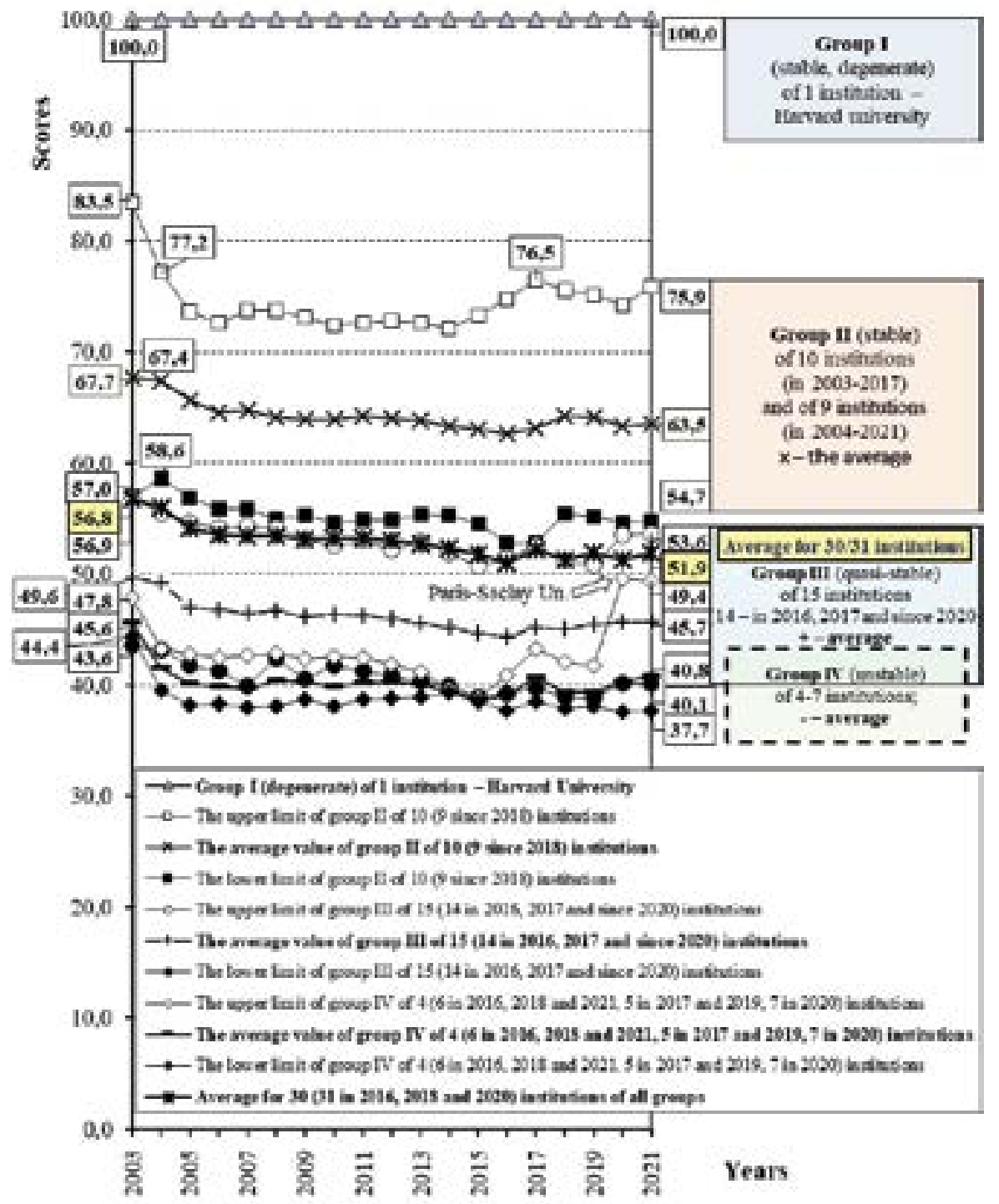

Fig. 5.

Stratification of universities into groups in the first 30 places of the Shanghai ranking in 2003-2021

Source: Compiled by authors based on: Shanghai Ranking, 2021. 
Fig. 6 shows how the number of ECUs and their average rating score within the group of top 30 Shanghai Ranking in 2021 has changed compared to 2003.

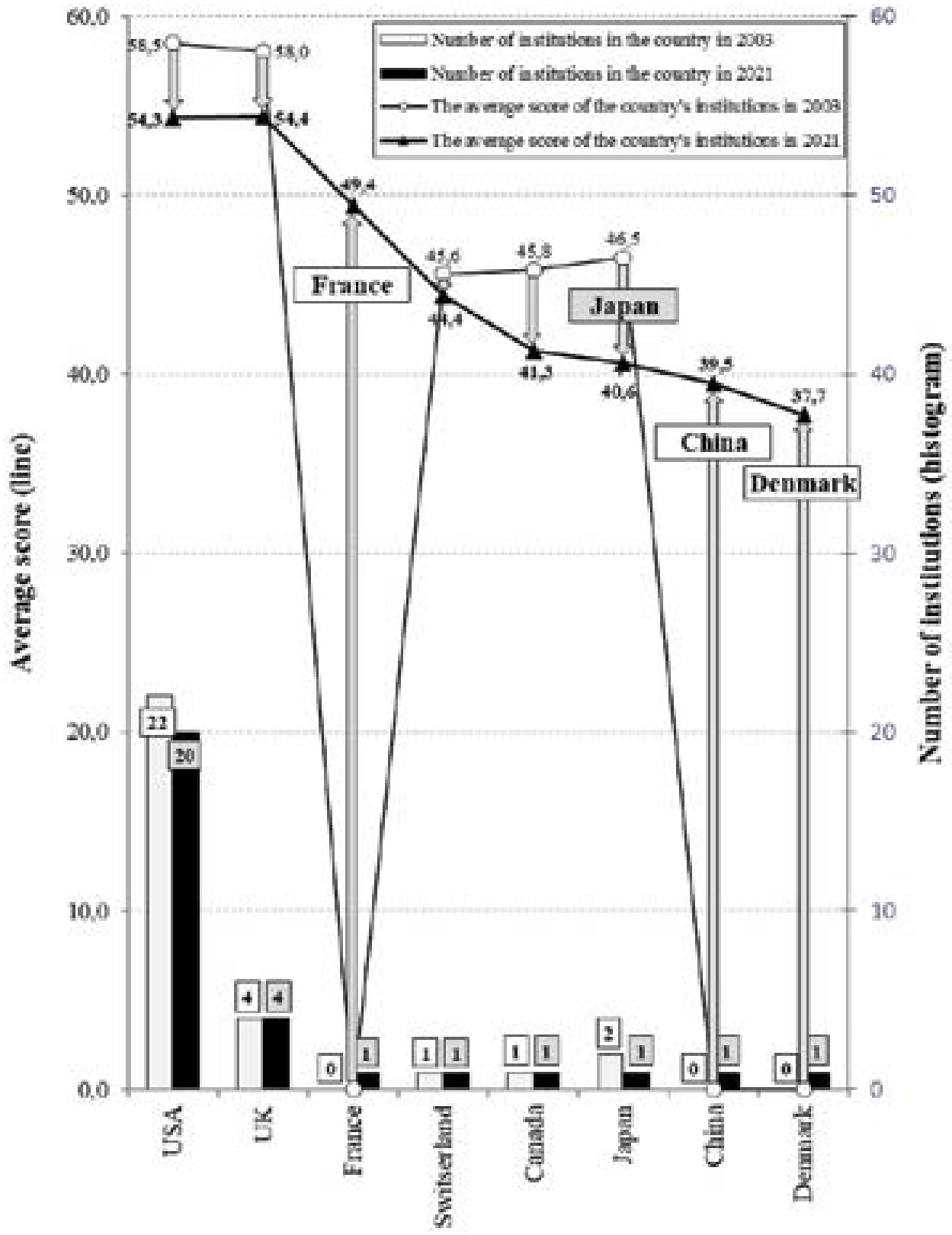

Countries in the order of the first place in the ranking

Fig. 6.

Comparative characteristics of universities in the countries represented by higher education institutions in the group of top-30 of the Shanghai ranking 2021, in 2003 and 2021

Source: Compiled by authors based on: Shanghai Ranking, 2021.

Fig. 7 shows similar quantitative and qualitative changes for WCUs in the 1-100 positions of the Shanghai Ranking. 


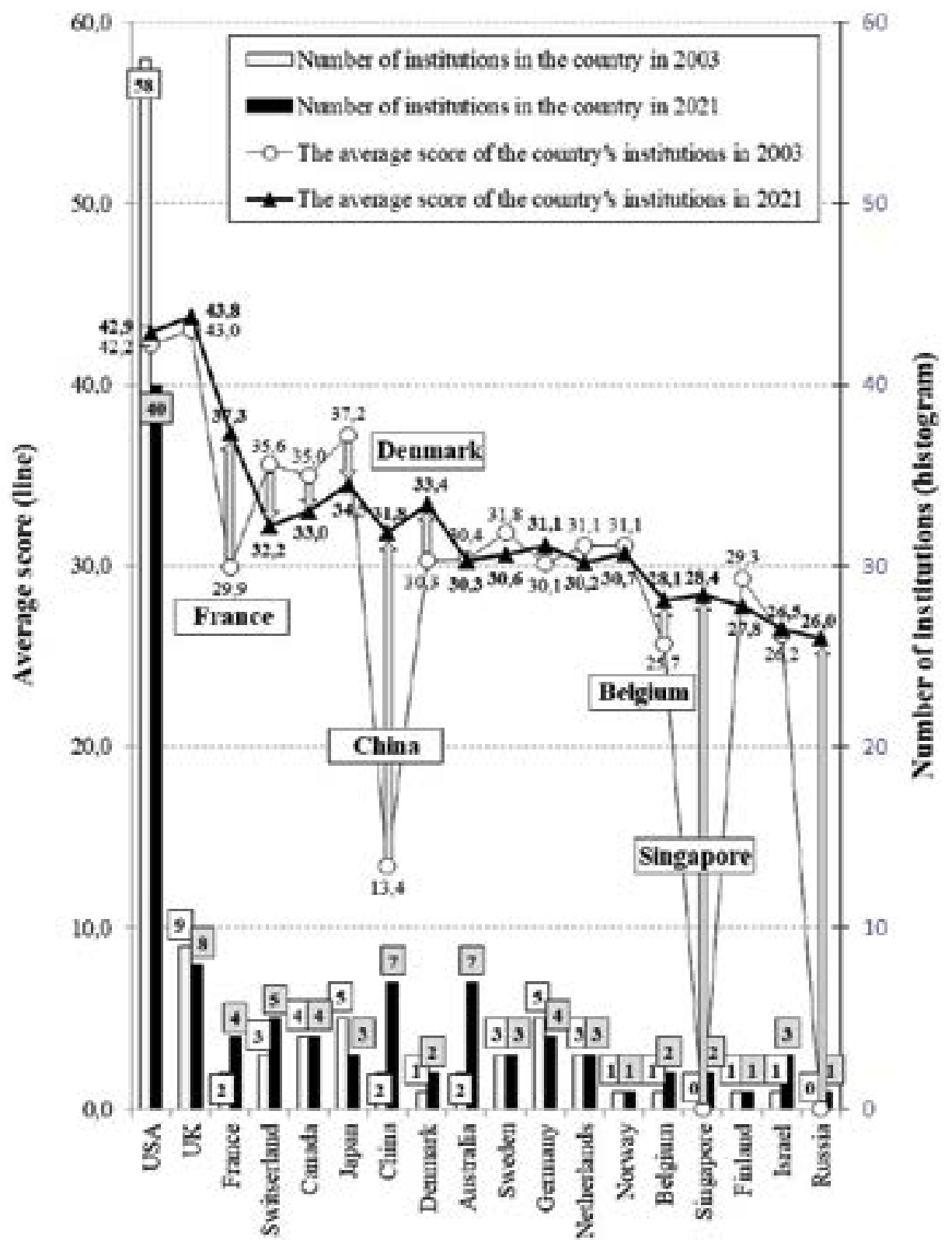

\section{Countries in the order of the first place in the ranking}

Fig. 7.

Comparative characteristics of universities in the countries represented by higher education institutions in the group of top-100 of the Shanghai ranking 2021, in 2003 and 2021

Source: Compiled by authors based on: Shanghai Ranking, 2021.

Considering Fig. 3, 4, 6, 7, it is possible to group the countries in which de facto there were certain similar changes in the quantitative and qualitative composition of WCUs and ECUs during 2003-2021, which is advisable to carefully analyse in order to use the best experience in Ukraine (Fig. 8). Indeed, for Ukraine, the task at this stage is much more modest: it is necessary, first of all, to achieve such a sufficient development of universities so that domestic institutions 
are generally noticed by the Shanghai Ranking. Currently, out of 63 countries / territories of the general version of Shanghai Ranking and 93 countries / territories of its sectoral version (in 54 academic subjects), Ukraine is absent (Shanghai Ranking, 2021).

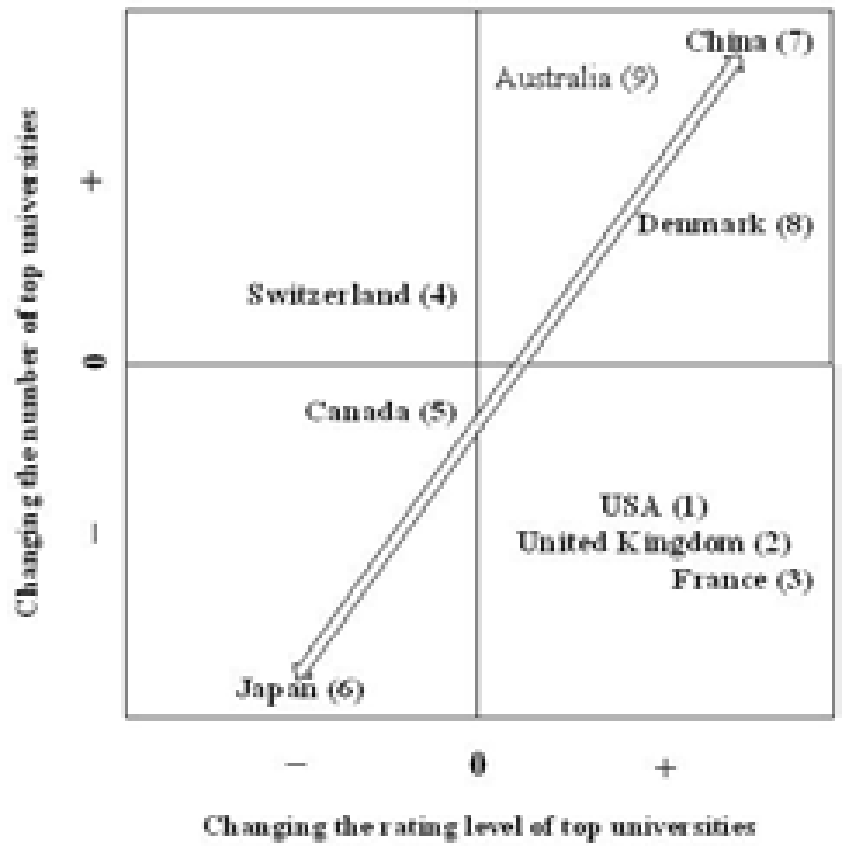

Fig. 8.

Strategic changes in the number and quality of top universities in the top 9 countries by university achievements according to the Shanghai ranking 2021, during 2003-2021

Source: Designed by authors based on: Shanghai Ranking, 2021.

Fig. 8 shows that the first group is made up of the countries in the first, second and third positions of the Shanghai Ranking - the USA, UK and France. For them, the strategic priority is to maintain / create ECUs and maintain / achieve their high level, and the overall reduction in the number of WCUs is not essential.

The strategic nature of university development in large China and small Denmark is similar to each other. For them, just like in the previous group, the presence of ECUs in the top 30 group is important. At the same time, China has increased the presence of WCUs in the top 100 and top 500. Denmark has increased WCU's presence in the top 100. In both countries, the average university scores increased.

Switzerland traditionally has ECUs and has increased the number of WCUs in the top 100 but lowered the rankings of universities.

In Canada, there is a slight decrease in both quantitative and qualitative indicators of universities.

In Japan, university education has changed in the opposite direction to neighbouring Chinese. The number of Japanese universities in the top 30 group decreased from 2 to 1 , in the top 100 from 5 to 3 , and in the top 500, as noted, from 36 to 12 . At the same time, the ranking indicators worsened. The country in the ranking moved from $3^{\text {rd }}$ to $6^{\text {th }}$ position, while China moved up from $25^{\text {th }}$ to $7^{\text {th }}$ place and came closer to Japan.

Australia's strategic university progress draws attention. The University of Melbourne, having gone from 92 to 33 places, is a real contender for ECU status. The country ranks 9th place, increased the number of WCUs in the top 100 group from 2 to 7 , in the top 500 from 13 to 24, ahead of France and Canada. 
The university stagnation in Germany cannot be ignored. The country, in contrast to neighbouring small Switzerland and Denmark, does not have ECUs, it has reduced the number of WCUs in the top 100 group from 5 to 4 , and the top 500 from 43 to 28 has dropped in general from 8 to 11 position. Best University of Munich is ranked $48^{\text {th }}$ (same as 2003).

Since Shanghai Ranking is unattainable to Ukraine, it remains to appeal to less objective international university rankings - THE and QS (Shanghai Ranking, 2021; THE..., 2021; QS..., 2021). According to the latest published data, they have a total of 11 Ukrainian establishments: 10 in the THE and 8 in QS (Table 1).

Table 1

\section{Positions of Ukrainian higher education institutions according to the ratings of THE and QS 2020-2022}

\begin{tabular}{|c|c|c|c|c|c|c|c|}
\hline \multirow[t]{2}{*}{$\mathbf{N}$} & \multirow[t]{2}{*}{ HEIs } & \multicolumn{3}{|c|}{$\begin{array}{l}\text { THE } \\
\text { years }\end{array}$} & \multicolumn{3}{|c|}{$\begin{array}{c}\mathrm{QS} \\
\text { years }\end{array}$} \\
\hline & & 2020 & 2021 & 2022 & 2020 & 2021 & 2022 \\
\hline 1 & 2 & 3 & 4 & 5 & 6 & 7 & 8 \\
\hline 1 & Lviv Polytechnic National Un. & $801-1000$ & $501-600$ & $601-800$ & $751-800$ & $801-1000$ & $801-1000$ \\
\hline 2 & Sumy State Un & $1001+$ & $501-600$ & $501-600$ & $701-750$ & $701-750$ & $701-750$ \\
\hline 3 & $\begin{array}{l}\text { Kharkiv National Un. } \\
\text { of Radio Electronics }\end{array}$ & - & $800-1000$ & $1001-1200$ & - & - & - \\
\hline 4 & $\begin{array}{l}\text { Ivan Franko National Un. } \\
\text { of Lviv }\end{array}$ & $1001+$ & $1001+$ & $1201+$ & - & - & $1001-1200$ \\
\hline 5 & $\begin{array}{l}\text { National Technical Un. } \\
\text { "Kharkiv Polytechnic Institute" }\end{array}$ & $1001+$ & $1001+$ & $1201+$ & $651-700$ & $651-700$ & $651-700$ \\
\hline 6 & $\begin{array}{l}\text { National Technical Un. } \\
\text { of Ukraine "Igor Sikorsky } \\
\text { Kyiv Polytechnic Institute" }\end{array}$ & - & $1001+$ & $1201+$ & $701-750$ & $701-750$ & $701-750$ \\
\hline 7 & $\begin{array}{l}\text { Taras Shevchenko } \\
\text { National Un. of Kyiv }\end{array}$ & $1001+$ & $1001+$ & $1201+$ & $541-550$ & $601-650$ & $601-650$ \\
\hline 8 & $\begin{array}{l}\text { V.N. Karazin Kharkiv } \\
\text { National Un. }\end{array}$ & $1001+$ & $1001+$ & $1201+$ & 491 & 477 & 511-520 \\
\hline 9 & $\begin{array}{l}\text { Yuriy Fedkovych Chernivtsi } \\
\text { National Un. }\end{array}$ & - & $1001+$ & $1201+$ & - & - & - \\
\hline 10 & $\begin{array}{l}\text { Oles Honchar Dnipro } \\
\text { National Un. }\end{array}$ & - & - & $1201+$ & - & - & - \\
\hline 11 & $\begin{array}{l}\text { National Un. of Kyiv-Mohyla } \\
\text { Academy }\end{array}$ & - & - & - & $1001+$ & $1001+$ & $1001-1200$ \\
\hline \multicolumn{2}{|c|}{ Number of ranked institutions } & 1397 & 1527 & $>1600$ & 1002 & 1002 & 1300 \\
\hline \multicolumn{2}{|r|}{ Number of countries, territories } & 92 & 93 & 99 & 82 & 80 & 97 \\
\hline
\end{tabular}

Source: Compiled by the authors based on: THE ..., 2021; QS .., 2021. 
The data of Table 1 indicate that, in general, the rating positions of Ukrainian institutions have worsened. There are no domestic institutions in the top 1-500 group, it means, there are no WCUs in Ukraine according to the versions of these ratings. There are few auxiliary ratings in identifying the first leading university in Ukraine, following the example of Harvard University in USA, University of Cambridge in UK or Paris-Saclay University in France.

\section{CONLUSIONS}

The following conclusions follow from the above.

1. Shanghai Ranking demonstrates high efficiency for assessing the top quality of higher education and identifying national strategies for the development of the highest university potential in world practice during 2003-2021. The strengths of this rating, which make it the most perfect today, are objectivity, validity, probability, reliability, transparency, clarity, parametric expediency, top-university mission compliance.

2. Application of Shanghai Ranking allows you to find out the main modifications of the university strategy-2 (strategy for the development of higher education of the highest quality). The most breakthroughs turned out to be the strategic initiative of France for a large concentration of university resources by integration of leading universities and China's strategy, which consists both in the amalgamation of universities and powerful targeted support of leading institutions. At the same time, in Japan, the lack of a coherent national strategy led to multiple losses of both world-class universities (in the top 500 ranking group) and extra-class universities (in the top 30 group).

3. Shanghai Ranking has shown the intensification of competition in the field of top higher education. The number of countries represented by universities in the top 30 , top 100 and top 500 groups has increased. The United States has worsened its position, although it remains the absolute world university leaders. The second ranking place is occupied by the UK. France moved to third place. China, occupying the $7^{\text {th }}$ step, came close to Japan at the 6 th position.

4. According to the data of the Shanghai rating, Ukraine increasingly lags behind progress in the world, is not included in the list of 63 countries / territories of the general version and up to 93 countries / territories of the sectoral (for 54 academic subjects) version of the 2021 rating. Ukraine for national security purposes needs urgent development and implementation of the national strategy-2 development of higher education.

\section{REFERENCES}

Cabinet of Ministers of Ukraine (2018). Rozporiadzhennia vid 14 bereznia 2018 r. № 154-r Pro zatverdzhennia pereliku svitovykh reitynhiv universytetiv dlia vyznachennia osoblyvoi katehorii inozemtsiv ta osib bez hromadianstva, yaki pretenduiut na pratsevlashtuvannia v Ukraini. Uriadovyi kurier, 56. http://zakon2.rada.gov.ua/laws/show/154-2018-\%D1\%80

IREG (2020). University rankings in time of uncertainty. Beijing conference. 20-21 October 2020. Retrieved November 9, 2021, from https://ireg-observatory.org/en/events/ireg2020-beijing-coference-virtual/

IREG (2021). IREG Observatory on Academic Ranking and Excellence. http://ireg-observatory. org/en/

Lugovyi, V., Slyusarenko, O. \& Talanova, Zh. (2019). University rating \& development: challenges and opportunities for Ukraine. Education: Modern Discourses, 2, 60-77. https://doi.org/10.32405/2617-3107-2019-1-8 Lugovyi, V., Slyusarenko, O. \& Talanova, Zh. (2020). Challenge of developing quality profile of higher education in Ukraine. Education: Modern Discourses, 3, 57-77. https://doi.org/10.37472/2617-3107-2020-3-06 
Lugovyi, V. (ed.), Talanova, Zh. (ed), Vorobiova, O., Debych M., ... \& Tryma K. (2018). Analiz providnoho vitchyznianoho ta zarubizhnoho dosvidu shchodo otsiniuvannia yakosti vyshchoi osvity v umovakh yevrointehratsii: analitychni materialy (chastyna I) (preprynt). In-t vyshchoi osvity NAPN Ukrainy. https://ihed.org.ua/wp-content/uploads/2019/08/ Analiz_ocinki_VO_v_umovah_internac_ch1_analit_IVO-2018-172p_avtors-kolektiv.pdf Luhovyi, V. \& Talanova, Zh. (eds.), Vorobiova, O., Debych M., ... \& Tryma K. (2020). Mekhanizmy otsiniuvannia yakosti vyshchoi osvity $v$ umovakh yevrointehratsii: monohrafia. https:// doi.org/10.31874/978-617-7486-38-0-2020

Luhovyi, V., Sliusarenko, O., \& Talanova, Zh. (2020a). Reitynhovyi rozpodil ta formulne finansuvannia ukrainskykh universytetiv: problema subiektyvizmu i nedoviry. Universytety i liderstvo: mizhnarodnyi naukovyi zhurnal, 2 (10), 35-69. https://doi. org/10.31874/2520-6702-2020-10-2-35-69

Luhovyi, V., Sliusarenko, O., \& Talanova, Zh. (2020b). Monitorynh, motyvatsiia, mobilizatsiia zadlia konkurentospromozhnosti universytetiv Ukrainy: mekhanizmy realizatsii. Visnyk Natsionalnoi akademii pedahohichnykh nauk Ukrainy, 2(2). https://doi.org/10.37472/2707305X-2020-2-2-13-1

NAQA Ukraine (2021). Natsionalne ahentstvo iz zabezpechennia yakosti vyshchoi osvity. https://naqa.gov.ua/

OECD (2009). Higher Education to 2030, Volume 2: Globalisation, Executive Summary. OESD Publishing. http://www.oecd.org/education/ceri/44101074.pdf

OECD (2021). Education at a Glance 2021: OECD Indicators. OECD Publishing. https://www. oecd-ilibrary.org/docserver/b35a14e5-en.pdf?expires=1635685949\&id=id\&accname=gu est\&checksum=EEFA90B2E2F14DC8C87A78C49BC220FD

OECD (2021a). Main Science and Technology Indicators. https://stats.oecd.org/viewhtml. aspx?datasetcode=MSTI_PUB\&lang=en

Prezydent Ukrainy (2020, 3 chervnia). Pro vdoskonalennia vyshchoi osvity v Ukraini (210). https://www.president.gov.ua/documents/2102020-34045

Prezydent Ukrainy (2021, 31 travnia). Pytannia proektu «Prezydentskyi universytet» (217). https://www.president.gov.ua/documents/2172021-39029

QS World University Rankings 2022 (2021). Retrieved November 9, 2021, from https://www. topuniversities.com/university-rankings/world-university-rankings/2022

Ranking Web of Universities (2021). http://www.webometrics.info/en

Salmi, Dzh. (2009). Sozdanie universitetov mirovogo klassa. Izdatelstvo «Ves Mir».

Shanghai Ranking. (2021). Retrieved November 9, 2021, from https://www.shanghairanking. $\mathrm{com} /$

Slyusarenko, O. M. (2015). Rozvytok naivyshchoho universytetskoho potentsialu v umovakh hlobalizatsii: monohrafiia. Priorytety.

Talanova, Zh. V. (2010). Doktorska pidhotovka u sviti ta Ukraini: monohrafiia. Milenium.

THE World University Rankings (2021). Retrieved November 9, 2021, from https://www. timeshighereducation.com/world-university-rankings/2022/world-ranking\#!/page/0/ length/25/sort_by/rank/sort_order/asc/cols/stats

University Quality Indicators: A Critical Assessment: Study. (2015). Retrieved November 9, 2021, from http://www.europarl.europa.eu/RegData/etudes/STUD/2015/563377/IPOL_ STU\%282015\%29563377_EN.pdf

Verkhovna Rada Ukrainy (2014). Zakon Ukrainy «Pro vyshchu osvitu» № 1556-VII. Vidomosti Verkhovnoi Rady (VVR), 37-38, 2004. http://zakon5.rada.gov.ua/laws/show/1556-18.

World Bank Group (2019). Review of the Education Sector in Ukraine. Moving towards Effectiveness, Equity and Efficiency (RESUME3). Overview.

http://documents.worldbank.org/curated/en/360951568662377063/pdf/Overview.pdf 